\title{
Oxidant/antioxidant status in serum of breast cancer women treated by surgical interference and chemotherapy
}

\author{
Imad AJ Thanoon*, Khalaf R Jadoa**, Faris A Ahmed*** \\ Departments of *Pharmacology and ${ }^{* *}$ Surgery, Mosul College of Medicine, ${ }^{* * *}$ Department of Physiology, Ninevah \\ College of Medicine, University of Mosul, Iraq
}

$\frac{\text { Received }}{\sum .0 . Y \cdot Y r} \quad \frac{\text { Accepted }}{\text { Y. } .9 .1 Y}$

\begin{abstract}
Objectives: The study was designed to assess lipid peroxidation and oxidative defense system in patients with breast cancer, following them from the time of diagnosis through surgery and treatment. .

Patients and Methods: The study was conducted in Al-Jammhori Hospital, Mosul, Iraq. Twenty three women with breast cancer types III and IV and $r$ r apparently healthy women as a control group were included in this study. Blood samples $\left({ }^{\circ} \mathrm{ml}\right)$ were taken from patients and controls and analysed for serum malondialdehyde (MDA) and total antioxidant status (TAS) concentration. Blood samples were taken from patients one week before and after the operation and other blood samples were taken two weeks after the first dose of infusion with a combination therapy of cyclophosphamide, - ${ }^{-}$fluorouracil and doxorubicin. The therapy was started two weeks after the surgery every 7 weeks for 7 cycles.
\end{abstract}

Results: In breast cancer women, serum MDA was significantly higher $(\mathrm{P}<\bullet . \cdots)$, whereas serum TAS was significantly lower $(\mathrm{P}<\bullet \cdot \cdots)$, compared with those of the control group. In patients, after breast surgery, serum MDA was decreased significantly $(\mathrm{P}<\cdot . \cdot)$, while serum TAS was increased significantly $(\mathrm{P}<\cdot \cdots \cdot)$, compared with those of the patients before operation. Chemotherapy treatment caused a significant elevation $(\mathrm{P}<\bullet, \cdot)$ ) in serum MDA associated with a significant reduction $(\mathrm{P}<\cdot \cdots)$ in serum TAS, compared with the patients before and after operation and also with the control group.

Conclusion: lipid peroxidation was increased in breast cancer women, while antioxidative defense system was decreased. Surgical removal of breast cancer decreased lipid peroxidation with an increase of antioxidant defense system. Lipid peroxidarion may be a consequence of cancer disease. Chemotherapy of breast cancer increased lipid peroxidation and depressed antioxidant defense system.

Keywords: breast cancer, lipid peroxidation, total antioxidant status, malondialdehyde.

$$
\begin{aligned}
& \text { الخلالصة من الاراسة: صممت هذه الدر اسة لتقييم زناخة الدهون ومنظومة مضادات الأكسدة في النساء الدصابات }
\end{aligned}
$$

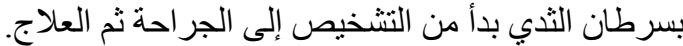

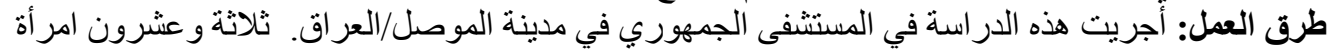

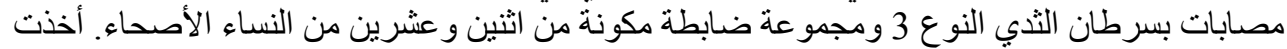

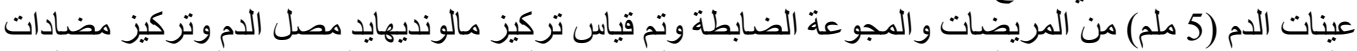

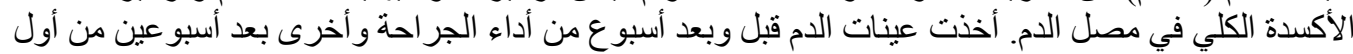

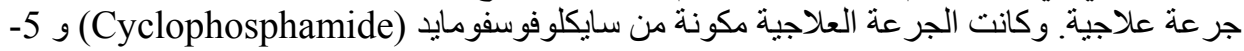




$$
\begin{aligned}
& \text { فلورويور اسيل (Doxorubicin) (D) و (D) و دكسوروبأت الجرع العلاجية بعد أسبو عين }
\end{aligned}
$$

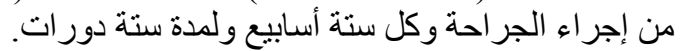

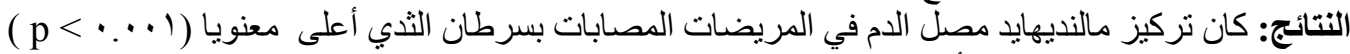

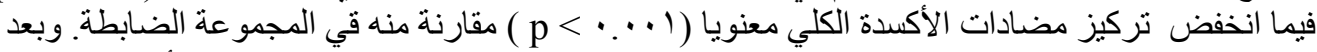

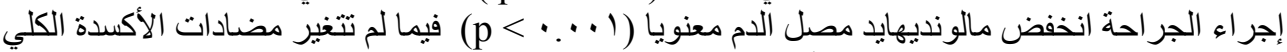

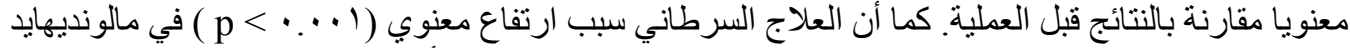

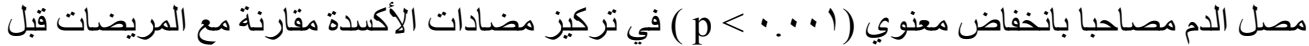

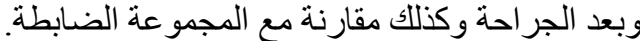

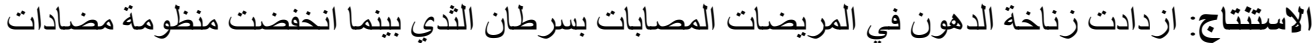

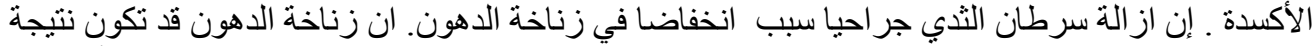

$$
\begin{aligned}
& \text { مرض السرطان. وان العلاج المضاد اللسرطان رفع من زناخة الدهان الدون وفلل من منظومة مضادادات الأكسدة }
\end{aligned}
$$

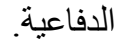

$\mathrm{O}_{\mathrm{p}}^{\mathrm{x}}$ xidative stress is implicated in the pathophysiology of breast cancer'. Generally, the increase of serum malondialdehyde (MDA) in breast cancer patients was supported by many workers ${ }^{r, r}$. However, plasma MDA was decreased in breast cancer patients , The decrease in plasma MDA was associated with the severity of tumor size in breast cancer patients .

Many studies found that plasma superoxide dismutase (SOD), catalase (CAT), total glutathione and vitamin $\mathrm{A}$ and $\mathrm{E}$ were decreased in breast cancer patients, suggesting the importance of endogenous antioxidants in the etiology of breast cancer ${ }^{7-9}$. On the other hand, glutathione peroxidase (GPX), and SOD were increased in breast cancer patients. Total antioxidant status (TAS) which is more valuable than individual antioxidants, was decreased in breast cancer patients'.

Many studies showed that chemotherapeutic agents increases lipid peroxidation in cancer patients $^{\prime 1,1 r}$, whereas total antioxidants were decreased by antineoplastic $\operatorname{drugs}^{\prime r}$.

The controversial results of lipid peroxidation in breast cancer patients and the interactions of individual antioxidants in the organism, noticed in the previous study, stimulated us to evaluate oxidative stress and antioxidant defense system in the cancer patients. The assessment was done by measurement of serum TAS instead of individual antioxidants. Other manipulation was used through measurement of serum MDA and TAS in the patients after removal of the cancer tissues. The study aims to examine lipid peroxidation and total antioxidant status in breast cancer patients following them from the time of diagnosis through surgery and treatment.

\section{Patients and methods}

This study received approval from Ninevah Directorate of Health (Medical Research ethical Committee). The study comprised $r$ r women with breast cancer stage III from the breast cancer center at Al-Jammhori Hospital, Mosul, Iraq, during the period from February to November $Y . . v$. Their ages ranged between $r \wedge$ to $r$. years (mean \pm SD: $\leqslant \uparrow . r \pm 0 . \wedge$ years). A control group of $r$ apparently healthy women were also included during that time from the same centre, their ages ranged between $r \cdot-\tau \Lambda$ years (mean \pm SD:

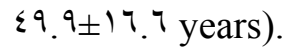

Blood samples $\left({ }^{\circ} \mathrm{ml}\right)$ were taken from patients and controls, and analysed for serum MDA ${ }^{1 \xi}$, 10 and serum TAS ${ }^{10,14}$ at the Department of Pharmacology, Mosul College of Medicine, University of Mosul, Iraq. 
The blood samples were taken from the patients a week before and after the operation and other blood samples were taken two weeks after infusion of the first dose of chemotherapy. Combination drugs of cyclophosphamide $\quad 0 . . \mathrm{mg} / \mathrm{m}^{r}$, $0_{-}$ fluorouracil $\quad 0 \cdot \mathrm{mg} / \mathrm{m}^{r}$, and doxorubicin $0 \cdot \mathrm{mg} / \mathrm{m}^{r}$ were started by infusion after two weeks of the surgery, every ${ }^{\top}$ weeks for six cycles.

The exclusion criteria for both patient and control groups were any other disease, drug treatment, smoking or alcohol intake. Data are presented by mean \pm SD. Paired t-test was used to compare between the follow up groups. Non paired t-test was used to compare between the control and patient groups.

\section{Results}

Serum MDA in the breast cancer women was significantly higher $(\mathrm{P}<$ $\because \cdots 1)$, whereas serum TAS was significantly lower $(\mathrm{P}<\because \cdots)$ than that in the control healthy women (Table 1).

After surgery serum MDA deceased significantly $(\mathrm{P}<\because \cdots)$, whereas serum TAS increased significantly $(\mathrm{P}<$ $\because \cdots 1)$, compared with the before operation in the patients (Table ').

In post-operative patients, a combination of cyclophosphamide, ${ }^{-}$ fluorouracil, and doxorubicin elevated serum MDA significantly $(\mathrm{P}<\bullet . \cdots)$ and reduced serum TAS significantly $(\mathrm{P}<\because \cdots)$ compared with these values in post-operative patients before treatment (Table ').

Table '. Serum MDA and TAS in breast cancer and control women

\begin{tabular}{|c|c|c|}
\hline & $\begin{array}{l}\text { Serum MDA } \\
(\mu \mathrm{mol} / \mathrm{L})\end{array}$ & $\begin{array}{c}\text { Serum TAS } \\
(\mathrm{mmol} / \mathrm{L})\end{array}$ \\
\hline $\begin{array}{l}\text { Control subjects } \\
\mathrm{N}=r r\end{array}$ & $\begin{array}{c}\cdot .91 \\
\pm \cdot .11\end{array}$ & $\begin{array}{l}\text { r.r } \\
\text { T. ro }\end{array}$ \\
\hline $\begin{array}{c}\text { Patients } \\
\mathrm{N}=\mathrm{r} \\
\text { Before surgery }\end{array}$ & $\begin{array}{l}r . \wedge 7^{a} \\
\pm \cdot .1 \wedge\end{array}$ & $\begin{array}{l}1 . r^{\mathrm{a}} \\
\pm \cdot .11\end{array}$ \\
\hline After surgery & $\begin{array}{l}r \cdot v)^{b} \\
\pm \cdot . r\end{array}$ & $\begin{array}{l}1 . r 0^{b} \\
\pm \cdot .14\end{array}$ \\
\hline After chemotherapy & $\begin{array}{l}r . \cdot \varepsilon c, d \\
\pm \cdot .17\end{array}$ & $\begin{array}{l}1 . V^{c, d} \\
\pm \cdot .1 \leq\end{array}$ \\
\hline
\end{tabular}

${ }^{\mathrm{a}} \mathrm{p}<\bullet .+1$ VS. Control, ${ }^{\mathrm{b}} \mathrm{p}<\bullet .+1$ VS. before surgery; $\left.{ }^{\mathrm{c}} \mathrm{p}<\bullet . \cdots\right)$ VS. after surgery, $\left.{ }^{\mathrm{d}} \mathrm{p}<\bullet . \cdots\right)$ VS controls. 


\section{Discussion}

This study attempted to clarify the controversial results in the literatures for lipid peroxidation and antioxidant defense system in breast cancer patients. Serum MDA and TAS were measured before and after removal of breast cancer in the studied patients. In addition, serum TAS was measured instead of individual antioxidants, since it covers all enzymatic and nonenzymatic antioxidants ${ }^{14}$.

In the present breast cancer women, serum MDA was increased with a significant reduction of total antioxidant defense system compared with the control group. These results are consistent with other studies ${ }^{\prime Y, 1}$. However, lipid peroxidation and individual antioxidants in the blood of breast cancer patients are still controversial $^{0,19-r r}$.

The change in lipid peroxidation in breast cancer as a cause or consequence remains to be clarified. Torun et al. ${ }^{r}$ suggested that measurement of MDA levels provides useful information in evaluating breast cancer. In the present breast cancer patients, surgical removal of breast cancer depressed serum MDA suggesting the implication of the breast cancer in causing lipid peroxidation.

After one week of surgical removal of the present breast cancer, serum TAS was significantly increased. The time of one week after surgery may be enough to regenerate the antioxidant defense system possibly reflecting the relief of oxidative stress caused by removal of the cancer. Erohla et al. ${ }^{\text {s }}$ surgical removal of lung cancer caused a reduction in total antioxidant capacity during the early hours after operation but after few months of surgical removal of the tumor, there was an augmentation in total plasma antioxidant.
In the present study, chemotherapy for the breast cancer showed a significant increase in serum MDA. These results are consistent with other workers $^{\text {ro }}$. Serum MDA in the treated patients was even higher than that in the patients before surgery. There is evidence that anticancer drugs exert their cytotoxic activity by free radical mediated mechanism ${ }^{4}$. In addition, suppression of cancer growth was enhanced by pro-oxidants ${ }^{r Y}$.

Mitochondria are the main site for reactive oxygen species (ROS) generation and are thought to be a major intracellular target for oxidative damage $^{r \wedge}$. Anticancer agents can cause mitochondrial permeabilization through enhanced generation of lipid peroxidation, and once the mitochondrial membrane barrier function is lost, several factors contribute to cell death ${ }^{r q}$. Moreover, Mitochondrial permibilization was facilitated by lipid peroxidation and antioxidant enzyme inhibited it ${ }^{r}$. Tandon et al. ${ }^{r}$ suggested that oxidative stress is not always detrimental, as it can be beneficial in cancer sometimes. Hence, oxidative stress can be as a double way sword in malignant states ${ }^{r}$.

Serum TAS was significantly decreased by chemotherapy compared with that before treatment, the free radical mediated mechanism of chemotherapy may exhaust the antioxidant defense system. ${ }^{\text {q }}$. In addition, the dietary depletion of vitamin $\mathrm{E}$ and vitamin $\mathrm{A}$ inhibited mammary tumor in mice ${ }^{r r}$.

In conclusion, breast cancer increased lipid peroxidation and depressed antioxidant defense system. Removal of breast cancer in women decreased lipid peroxidation. Lipid peroxidarion may be a consequence of cancer disease. Chemotherapy of breast cancer increased lipid 
peroxidation and depressed antioxidant defense system in breast cancer women.

\section{Acknowledgement}

This work was supported by Mosul College of Medicine, University of Mosul, Iraq.

\section{References}

1- Gago-Dominguez M, Castelao JE, Pike MC, Sevanian A, Haile RW. Role of lipid peroxidation in the epidemiology and prevention of breast cancer. Cancer Epid Bio Prev r...o, I s:r人rq_rArq.

r. Khanzode SS, Muddeshwar MG, Khanzode SD, Dakhale N. Antioxidant enzymes and lipid peroxidation in different stages of breast cancer. Free Radic Res r.. $\varepsilon ; r \wedge: \wedge l-\wedge 0$.

r- Tas F, Hansel H, Belce A, et al. Oxidative stress in breast cancer. Med Oncol Y...0; r Y : 1) _ 10.

¿- Alagol H, Erdem E, Sancak B, et al. Nitric oxide biosynthesis and malondialdehyde levels in advanced breast cancer. Aust N Z J surg 1999;79:7 $\leqslant \vee-70$.

o- Gerber M, Astre C, Segala C, et al. Tumor progression and oxidantantioxidant status. Cancer letters

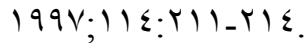

7. Kasapovic J, Pejic S, Todorovic A, et al. Antioxidant status and lipid peroxidation in the blood of breast cancer patients of different ages. Cell Biochem Funct r..A; r ฯ:VYr. $\mathrm{VT} \cdot$

V- Yeh CC, Hou MF, Wu SH, et al. A study of glutathione status in the blood and tissues of patients with breast cancer. Cell Biochem Funct Y.. T; r $\{: 000.009$.

^. Sharhar S, Normah H, Fatimah A, et al. Antioxidant intake and status, and oxidative stress in relation to breast cancer risk: a case-control study. Asia Pac J Prev r.. ^; $q: r \leqslant r-$ $r \leqslant 9$.

9- Torun M, Akgul, Sargin H. Serum vitamin $\mathrm{E}$ level in patients with breast cancer. J Clin Pharm Ther $1990 ; . \cdot: 1 V \mathrm{TH}_{-}$IVA.

1.-Sener DE, Gonenc A, Akinci M, Torun M. Lipid peroxidation and total antioxidant status in patients with breast cancer. Cell Biochem Funct $r \ldots V ; r o: r V V_{-} \wedge r$.

1)-Subramaniam S, shyamala $\mathrm{S}$, Jagadeesan M, Shyamala Devi C. Oxidant and antioxidant levels in the erythrocytes of breast cancer patients treated with CMF. Med Sci Res $199 r ; r): \vee \cdot-\Lambda \cdot$.

Ir-Faber M, Coundray C, Hida H, et al. Lipid peroxidation products, and vitamin and trace element status in patients with cancer before and after chemotherapy, including Adriamycin, A preliminary study. Bio Trace Elem Res 1990; \&V:1) $1 V_{-} \mid Y T$.

ir Papageorgiou M, Stiakaki E, Dimitriou $\mathrm{H}$, et al. Cancer chemotherapy reduces plasma total antioxidant capacity in children with malignancies. Leukemia Res r...o; rq: 11-17.

I $\leqslant$ Buege JA, Aust SD. Microsomal lipid peroxidation. Methods Enzymol १९४A; or: r.r.r।.

10 Thanoon IAJ, Ahmed FA, Jadoo KR. Lipid peroxidation and antioxidant status in Post-operative patients with cancer treated with chemotherapy. Zanco $r \cdot 1 \cdot ;$ Is (special issue $r$ ): $7 \varepsilon_{-} T$ V.

17 Miller NJ, Rice-Evans C, Davies $\mathrm{MJ}$, et al. A novel method for measuring antioxidant capacity and its application to monitoring the antioxidant stauts in premature neonates. Clin Sci 199r; $\wedge \varepsilon$ : $\varepsilon \cdot V_{-}$ s).

IV Kumar K, Thangaraju M, Sachdanandam P. Changes 
observed in antioxidant system in the blood of postmenopausal women with breast cancer. Biochem Int 1991; ro: rVI_rA.

is Kumaraguruparan R, Subapriya R, Kabalimoorthy J, Nagini S. Antioxidant profile in the circulation of patients with fibroadenoma and adenocarcinoma of the breast. Clin Biochem r..r.ro:rvo-rvq.

19 Ray G, Batra S, Shukla NK, et al. Lipid peroxidation, free radical production and antioxidant status in breast cancer. Breast cancer Res Treat $Y \ldots ; 09: 17 r-1 V \cdot$.

$r$. Seven A, Erbil Y, Seven R, et al. Breast cancer and benign breast disease patients evaluated in relation to oxidative stress. Cancer Biochem Biophys 1991;17. $r \leq 0$.

r) Polat MF, Taysi S, Gul M, et al. Oxidant/antioxidant status in blood of patients with malignant breast tumour and benign breast disease. Cell Biochem Funct r...r.r.:rrv_ rTI.

ir Yeh CC, Hou MF, Tsai SM, et al. Superoxide anion radical, lipid peroxides and antioxidant status in the blood of patients with breast cancer. Clin Chim Acta

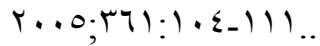

ir Torun M, Yardim S, Gonenc A, et al. Serum beta-carotene, vitamin E, vitamin $\mathrm{C}$ and malodialdehyde levels in several types of cancer. $\mathrm{J}$ Clin Pharm Ther 1990; r.: ro9_r r.

$r$ Erohla M, Nieminen MM, Kellokumpu-lehtinen P, et al.. Effects of surgical remaoval of lung cancer on total plasma antioxidant capacity in lung cancer patients. J Exp Clin Cancer Res 1991;|V:r/9_rrA.

ro Look MP, Musch E. Lipid peroxides in the polychemotherapy of cancer patients. Chemotherapy $199 \leqslant ; \varepsilon \cdot:$ _ 10 .

rч Takeda S, Horrobin DF, Manku M, et al. Lipid peroxidation in human breast cancer cells in response to gamma-linolenic acid and iron. Anticancer Res 1994; 1 r:rrq_rrr.

rv Welsch CW. Review of the effects of dietary fat on experimental mammary gland tumorigenesis: role of lipid peroxidation, Free Radic Bio Med 1990;1^: ov_vVr,

$\checkmark \wedge$ Richer C. Nitric oxide and its congeners in mitochondria: implication for apoptosis. Inviron Health Perspect 1991.0:11 ro-11r.

rq Costantini P, Jacotot E, Decaudin D, Kroemer G. Mitochondrion as a novel target of anticancer chemotherapy. J Natl Cancer Inst

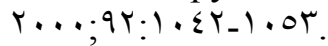

r. Mantymaa P, Siitonen T, Guttorm $\mathrm{T}$,et al. Induction of mitochondrial manganese superoxide dismutase confers resistance to apoptosis in acute myeloblastic leukaemia cells exposed to etoposide. $\mathrm{Br} \mathrm{J}$

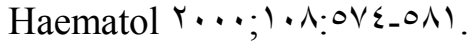

r) Tandon VR, Sharma S, Mahajan A, Bardi GH. Oxidative stress: a novel strategy in cancer treatment. JK Science $r . .0 ; V^{\prime}: 1-r$.

rr Subramaniam S, Subramaniam S, Shyamala Devi CS. Erythrocyte antioxidant enzyme activity in CMF treated breast cancer patients. Cancer Biochem Biophys $\left.1995 ; 1 \leq: 1 V V_{-}\right) 1 \mathrm{r}$. 